\title{
Internationalizing teacher education curricula: opportunities for academic staff development
}

\begin{tabular}{|r|l|}
\hline Journal: & On The Horizon \\
\hline Manuscript ID & OTH-07-2017-0053.R1 \\
\hline Manuscript Type: & Research Paper \\
\hline Keywords: & $\begin{array}{l}\text { global education, internationalization, curriculum development, teacher } \\
\text { education, professional development, participatory action research }\end{array}$ \\
\hline \multicolumn{2}{|l}{} \\
\hline
\end{tabular}

SCHOLARONE ${ }^{\text {w }}$

Manuscripts

This is an Author Accepted Manuscript (post-print) of an article published as EarlyCite by Emerald Insight in On the Horizon on 10 July 2018, available at https:// www.emeraldinsight.com/doi/full/10.1108/OTH-07-2017-0053

To cite this document:

Lourenço, M. (2018). Internationalizing teacher education curricula: opportunities for academic staff development. On the Horizon. https://doi.org/10.1108/OTH-07-2017-0053 


\begin{abstract}
Purpose - The purpose of this study is to understand the impact of a collaborative workshop, aimed to support teacher educators in embedding a 'global outlook' in the curriculum, on their perceived professional development.

Design/Methodology/Approach - The workshop included working sessions, during a period of 13 months, and was structured as participatory action research, according to which volunteer academics designed, developed and evaluated global education projects in their course units. Data was gathered through a focus group session, conducted with the teacher educators at a final stage of the workshop, and analyzed according to the principles of thematic analysis.
\end{abstract}

Findings - Results of the analysis suggest that the workshop presented a meaningful opportunity for teacher educators to reconstruct their knowledge and teaching practice, to (re)discover the importance of collaborative work, and to assume new commitments to themselves and to others.

Originality/Value - The study addresses a gap in the existing literature on academic staff development in internationalization of the curriculum, focusing on the perceptions of teacher educators', whose voices have been largely silent in research in the field. The study concludes with a set of recommendations for a professional development program in internationalization of the curriculum.

Keywords global education, internationalization, curriculum development, teacher education, professional development, participatory action research

Paper type Research paper

\title{
Introduction
}

Preparing tomorrow's teachers to take their place as ethical citizens and professionals in a globalized world is complex and requires that academic staff is both engaged and committed to the task. However, academics often report feeling unprepared, underconfident and undersupported when it comes to (re)designing (i.e., internationalizing) the curriculum to reflect a more global perspective (Green \& Whitsed, 2015). Some authors suggest that this might be related to unclear conceptualizations of internationalization of the curriculum (loC) (Childress, 2010; Stohl, 2007); to insufficient skills, knowledge and attributes to do so effectively (Leask, 2007; Sanderson, 2008); or to disciplinary differences, with staff in science and technology being generally less open to innovation than those in the humanities and social sciences (Clifford, 2009; Sawir, 2011). This makes it important to create times and spaces for academics to (re)construct knowledge in a collaborative way, and to ensure that loC extends beyond those disciplines where staff have an existing interest or predisposition.

So far, there is little extant research on the professional development of academic staff in loC (Leask, 2015) and more empirical studies are needed to shed light on this issue and foreground academic voices. This is the aim of this study, which sought to understand the impact of an loC workshop on the professional development of teacher educators through analyzing their discourses on the workshop and on their teaching practices. The following sections describe the context and theoretical framework supporting this study. These are followed by a detailed description of the workshop, the participants, and the methodology. Then, the main results are presented, supported by quotations of the teachers' interactions in a focus group. The paper ends with concluding remarks, including recommendations for a professional development program in loC.

\section{Globalization, internationalization, and teacher education}

In a globalized world characterized by unprecedented technological evolution, transnational mobility and employment, and large-scale migration, teachers face new and unexpected challenges. They need to keep pace with rapidly developing knowledge areas and approaches to learning and assessment, use new technologies, promote equality and social justice, respond effectively to children with different learning styles or behavioral problems, as well as to those with different linguistic and cultural backgrounds. Simultaneously, 
teachers need to be capable of preparing students (from or living in any part of the world) to engage with society and be autonomous lifelong learners (Darling-Hammond \& Lieberman, 2013; Schleicher, 2012).

In light of this context, several authors (see, among others, Quezada, 2012; Zeichner, 2010; Zhao, 2010) have been advocating the need to integrate global education (GE) in teacher preparation programs to help prospective teachers respond to the needs of today's classrooms and meet the imperatives presented by a global milieu. Despite being part of educational discourses and agendas since the mid-1960s, GE has gained relevance in recent decades, representing a new paradigm of the educational mission in the 21st century (Zinser, 2012). According to Tye (2014), GE involves 'learning about those problems and issues that cut across national boundaries, and about the interconnectedness of systems' ( $p .856)$. For the Council of Europe (2002), GE is 'education that opens people's eyes and minds to the realities of the world, and awakens them to bring about a world of greater justice, equity and human rights for all' (p.66). Hence, GE is transformative learning that involves a deep shift in the basic premises of thoughts, feelings and actions.

Although there seems to be little disagreement about the need to include a global dimension in teacher education programs, there remains little consensus around what exactly globally competent teachers need to know and how teacher preparation might be best conducted (Goodwin, 2012). Zhao (2010) and Zeichner (2010), however, seem to agree on some of the necessary dispositions, attitudes, knowledge and skills to teach in globally competent ways. These include such things as knowledge and understanding of the international dimensions of teaching and a range of global issues; foreign language proficiency and a deep understanding of other cultures; pedagogical and didactic knowledge and skills to educate students from diverse backgrounds and to help them acknowledge multiple points of view; ability to develop local, national and international partnerships; intellectual curiosity and problem solving skills; and a commitment to assisting students to become responsible citizens both of the world and of their own communities.

Nonetheless, these competences are not always sufficiently developed in teacher education programs (O'Connor \& Zeichner, 2011). In part, this is due to the fact that teacher education is still widely considered a matter of national interest, an attitude that goes back to the construction of nation-states and the creation of education systems in the 18th and 19th centuries. Thus, many teacher education programs still focus on preparing teachers for the national market, as well as on transmitting knowledge about methods and procedures appropriate to local contexts and groups. Although knowledge about the local is necessary, it is not sufficient to educate individuals to act and live in this complex world. Therefore, and given the homogeneous profile that still characterizes the teaching candidates (Patrick et al., 2014), some higher education institutions have been internationalizing teacher education curricula through the intentional integration of an international, intercultural or global perspective in the content, learning objectives, methodologies, activities and assessment tasks of a program of study (Leask, 2015). Among educational experiences are overseas mobility, design and development of research projects in multicultural environments, international online collaboration, and integration of the experiences and perspectives of mobile students. Hence, teacher educators are urged to move beyond their comfort zones in order to prepare prospective teachers for the globally interdependent world in which they will work and their students will live.

\section{Internationalisation of the curriculum and academic staff development}

Academic staff play a pivotal role in internationalization of the curriculum (loC), since it is they who set the aims and objectives, design the course(s) of instruction, select the content and activities, determine the methods of teaching, and set the learning tasks and assessments. Yet, academic staff are often uncertain what loC means, do not have the required skills, knowledge and attitudes to do so effectively, or do not think it has anything to do with them. Academics often reveal to be puzzled as to how to connect institutional internationalization goals with their disciplinary research agenda (Childress, 2010), and tend to regard the process as being the exclusive task of international offices (Leask et al., 2013). Researchers have also observed a marked difference in engagement in loC between disciplines. Sawir (2011) and Clifford (2009) both report that staff in humanities and social sciences are generally more open to innovation than those in science and technology, who tend to view their discipline as being inherently international in nature.

The requirement to integrate an intercultural or global perspective throughout the curriculum is also particularly challenging for academics, because it involves epistemological change (Leask, 2015). Drawing on a sample of educators within a university with a high proportion of international students, Sawir (2013) reports a prevailing view that the latter form a positive resource, but one from which 'home' students tend not to benefit. This suggests that some staff are not equipped to realize the potential that exists within the international classroom. Hence, 'internationalization of the academic Self' (Sanderson, 2008) is vital for loC. In other words, loC requires curriculum as well as personal transformation. If today's 'ideal graduate' is an interculturally 
competent, socially responsible, and globally aware citizen, the 'ideal lecturer' should also engage with, manage and learn from other cultures (Leask, 2007).

This calls for critically grounded staff development to foster the knowledge, skills and attributes many academics feel they do not possess. Some studies have offered ideas to support staff development for loC. For instance, Beelen and Jones (2015) highlight the need to focus on helping academics internationalize existing, discipline specific learning outcomes within the home curriculum for all students. Leask and Bridge (2013) make the case for senior support for internationalized curriculum development, with appropriate time allowances and reward structures. Luxon and Pello (2009) stress the relevance of bottom-up staff-led developments in pedagogic and curriculum thinking. De Wit and Beelen (2013) and Leask (2015), for their part, suggest that a contextualized approach to IoC, using participatory action research and conducted in disciplinary teams at department-level, may have better results. Still the number, scope and depth of studies focused on the professional development of academic staff for loC is limited (Green \& Whitsed, 2015). Therefore, more studies are needed to shed more light on this issue and foreground academic voices, particularly teacher educators' who play a decisive role in the preparation of globally competent teachers. This was the aim of this study which sought to understand the impact of a collaborative workshop on loC on teacher professional development.

\section{The study}

\section{The collaborative workshop}

The workshop took place in a Portuguese public university and aimed to support university faculty engaged in teacher education in embedding a 'global outlook' in courses for prospective pre-primary and elementary school teachers. More particularly, it pursued the following goals:

1. to stimulate critical reflection around the concepts of loC and GE;

2. to foster analysis and reflection around practices related with the internationalization of teacher education curricula and GE;

3. to assist teacher educators in designing, developing and evaluating action research projects in their course units (the focus of loC) to promote student teachers' global competence;

4. to contribute to teachers' professional development.

To achieve these goals eight two-hour sessions were conducted during a period of 13 months. These were structured as participatory action research (Kemmis \& McTaggart, 2007), whereby teams of two or three academics responsible for a course unit actively inquired into their own teaching and their students' learning to inform their understandings and make improvements. This methodology positioned the academic staff as equal and collaborative partners in research, and placed the researcher as an 'informed outsider' and a facilitator, encouraging, assisting, and guiding the teacher educators through the process of IoC. The intention was to avoid the situation of an 'outside expert' coming in to take over the curriculum review process, a situation that is often resisted (Leask, 2015).

The workshop was organized according to four stages (Figure 1), which roughly followed the diagrams of action research and their distinctive phases (Lewin, 1946). In Stage 1 of the project, 'Knowing and Sharing', three discussion sessions took place to share and construct knowledge around the concepts and practices of IoC and GE. The first session was dedicated to characterizing the working group and understanding their representations regarding the concepts of IOC, GE, and teacher profile. The second session focused on establishing a common definition for an internationalized curriculum; on discussing the knowledge, skills and attitudes that globally competent teachers should develop; and on designing internationalized learning outcomes. In the third session, attention was drawn to the analysis of case studies describing loC practices in teacher education courses in different countries. During Stage 2, 'Planning and Collaborating', two group sessions were conducted to support teacher educators in planning the action research GE projects. Stage 3, 'Acting and Developing', covered a five-month period during which the participating teachers staged the projects in their course units. During this period, one group session was conducted to take stock of the projects and discuss the major constraints encountered by the teachers. Individual meetings with the teams were also carried out, where the researcher acted as a 'critical friend', providing ideas and resources. Stage 4, 'Evaluating and Reflecting', which is still underway, marked the final stage of the workshop. It included a focus group session, which is at the heart of this study, and a final session, which will take place at the end of the academic year to allow the participants to present the results of the projects, evaluate the work developed by the group, and think about possible lines of action, namely a new cycle of action research. 
[Figure 1. Key stages of the collaborative workshop]

\section{Participants}

A total of twelve female teacher educators from an Education Department of a Portuguese public university participated as volunteers in the workshop, but only seven planned and developed GE projects. These constituted the case to be analyzed. Despite having similar academic backgrounds and teaching in similar disciplinary areas, these teachers were very diverse in terms of working years (see Table 1). Considering the five professional development stages identified by Huberman (1989), one teacher was in the career entry stage (less than 3 years in profession), another teacher was in the experimentation/diversification stage (7 to 18 years in profession), one teacher was in the serenity stage (19 to 30 years in profession), and four teachers were in the disengagement stage (31 to 40 years in profession). Apart from their teaching duties, six teachers performed other roles in the institution (e.g., as course directors, coordinators of research labs, or members of the Direction Board). All teacher educators, except for Laura and Kate, were born and raised in Portugal. Nonetheless, they all had extensive international experience, mainly related with participation in international research projects and scientific events, supervision of international students, and research/teaching periods abroad. The research focus of four of these teachers (Adelaide, Fatima, Laura and Rita) was on plurilingual and intercultural education. So, in general, teacher educators were predisposed to integrate a global/international perspective in the curriculum, but were unsure of how this could be carried out. The focus of the loC program was, then, to assist teacher educators in designing, developing and evaluating GE projects in their course units.

[Table 1. Description of the participants]

\section{The global education projects}

A total of four GE projects were designed by the seven teacher educators organized in groups of two (one teacher worked simultaneously in two groups) and staged in the following courses during the academic year 2016/2017:

- Educational Intervention Projects, BA in Basic Education (3rd year);

- $\quad$ Didactics of the Portuguese Language, Masters in Teaching (1st year);

- Linguistic Diversity and Education, Masters in Teaching ( $2^{\text {nd }}$ year, optional);

- Seminar in Educational Intervention and Practicum, Master's in Pre-Primary and Primary School Education (2nd year).

A total of 64 students were involved in the projects, the majority of which were Portuguese nationals with no mobility experiences. In one of the subjects (Educational Intervention Projects), there was a Spanish student who was studying in Portugal under the Erasmus program.

The strategies and activities selected by the teacher educators for their students were mainly of six types: (i) attending guest lectures by foreign teachers or experts on GE; (ii) reading, analyzing and presenting texts on GE or interrelated fields; (iii) writing linguistic and/or intercultural biographies; (iv) designing (and, in some cases, developing and evaluating) activities or action research projects on GE, often involving the local community; (v) presenting the projects in class; (vi) writing reports and/or reflections on the projects. The learning outcomes were in alignment with these strategies, addressing critical thinking, communication, argumentation, reflection, collaboration and intercultural skills, and aiming to promote students' sense of identity and self-esteem, valorization of diversity, concern for the environment, commitment to sustainable development, and social responsibility. Hence, both strategies and learning outcomes are in tune with the literature on GE.

\section{Data collection and analysis}

Consistent with the methodology of qualitative case studies (Yin, 2009), a variety of data sources was used to facilitate exploration of the perceptions and experiences of the group of the teacher educators who conducted these projects. Therefore, the following data were collected: audio recordings of the group sessions, including the one carried out as focus group; lesson plans and resources of the GE projects developed so far by the teacher educators; and observation notes taken during the sessions. The focus of this study falls on the results of the focus group. 
Focus groups are a form of qualitative research consisting of in-depth interviews employing relatively homogenous groups to discuss and comment on, from personal experience, the topic specified by the researchers (Krueger \& Casey, 2015). They are usually preferred to more conventional data collection techniques, as they reveal dimensions of understanding that other methods cannot reach. In a final stage of a study, focus groups are used to discuss with the participants the results obtained, accessing their perceptions and experiences. This was the goal of the focus group session carried out in this study, where participants were asked to share their perceptions, opinions and beliefs around questions related with the integration of a global perspective in their course units, and the perceived impact of the workshop on their professional development.

The transcripts of the focus group were analyzed using the principles of thematic analysis (Braun \& Clarke, 2006). Like most research methods, thematic analysis can occur in two primary ways - inductively or deductively. In an initial stage of this study, deductive coding was used to create a start list of potential codes that reflected the literature on teacher professional development, the ultimate goal of the collaborative workshop. These codes were then refined to create themes and sub-themes for more efficient analysis. In this latter case, inductive coding was used, drawing on the data. The coding process for each theme and subtheme was initially conducted by the author and then checked for validity by another researcher through a peer debriefing process. The themes and results of the analysis were also shared with the participants in the study to elicit feedback. This process aimed at enhancing trustworthiness, credibility and resonance of the findings.

Thematic analysis resulted in the identification of three themes: professional knowledge, teaching practice, and professional identity, which are considered areas of change in teacher professional development (see, for instance, Lourenço et al., 2014). Teacher professional knowledge is a combination of diverse types of knowledge (academic, institutional, practical) that teachers draw upon in order to respond to the needs of their students. According to Shulman (2004), it not only includes subject matter expertise and pedagogical knowledge, but also knowledge about the historical and philosophical principles of education, as well as knowledge about the curriculum. Teaching practice includes the pedagogical and didactic repertoire of the teacher, which rests on teachers' previous knowledge and experience, but also on cultural context and professional traditions (Porter et al., 2000). Teacher's professional identity refers to the set of attitudes, beliefs, experiences and ideals that define teachers in their professional careers (Goodnough, 2011). For each of these themes a set of sub-themes was also identified drawing on the data, as outlined in Table 2.

[Table 2. Themes and sub-themes emerging from data analysis]

\section{Results and discussion}

Results are presented and discussed according to each theme. In keeping with the aim to foreground academic voices, statements are illustrated by quotations, which provide fairly representative perspectives of the larger group of participants. All quotations were translated from Portuguese into English for purposes of clarity, and teachers' names were changed to preserve anonymity.

\section{Professional knowledge}

Regardless of their working experience and roles, all the teacher educators who participated in this workshop mentioned that they had (re)constructed knowledge related with IoC and GE. For Laura, the workshop presented an opportunity to question previous conceptions she had. As she admitted, 'internationalizing the curriculum through integrating a global perspective is more than welcoming foreign students, it is to rescue the link of what apparently divides us'. Concerning GE, teachers were initially unaware of this concept, envisaging it as a holistic form of education. During the sessions, however, teachers came to understand it as 'a new educational paradigm' (Carla), 'a way to see and "do" education' (Kate), which 'does not add to the subjects [they] have to teach, but rather implies a change in perspective' (Miriam). For these academics, GE is better understood as an 'umbrella term' for other themes that are already part of the curriculum, as well as a suitable perspective to guide and give meaning to their teaching practice. The following quotes illustrate these statements:

Fatima: One of the strengths of GE is the possibility to articulate themes that we already work with [...] but which were not seen under this perspective, namely education for sustainability and plurilingual and intercultural education. 
Carla: The greatest advantage I personally found in GE was the possibility it gave me to connect the course units I teach and all the work I do and put them inside a box ... Well, not quite a box. A box is a locked thing ... It gave me more comfortable glasses ... more comfortable, no ... you can see better...

Kate: Corrective lenses. [Laughs]

Fatima: To see both near and far. [Laughs]

Adelaide: To see the local and the global.

The workshop also contributed to a broader understanding of the curriculum as something that is flexible, that should be managed in a collaborative and cross-curricular manner, and that can include other contents, methodologies and goals, as Adelaide and Laura emphasize:

\begin{abstract}
Adelaide: I think that GE helps us manage the curriculum in a more flexible way and not to be 'stuck' with certain things or working according to certain themes.

Laura: GE allowed me to look beyond my immediate space of action and to find in it connections with a planetary experience. In what concerns teacher education, this step was taken when we were provoked to think beyond the limits of the course unit, in order to understand how we could integrate this global outlook in the curriculum.
\end{abstract}

This is in accordance with Leask (2015), who suggests that a fundamental step in loC is imagining other possibilities and new ways of thinking, challenging previous paradigms and conceptions, and thinking 'outside the box'. When conducted within a small group, she adds, this process stimulates creative thinking and experimentation, contributing to changes in teaching practice.

\title{
Teaching practice
}

In order to integrate a global perspective in the curriculum and respond more effectively to the current demands of their job, of their communities and of the society as a whole, teacher educators felt the need to extend their pedagogical and didactic repertoire. In some cases, this meant they had to 'dig deeper and find broader and more diversified resources' (Fatima). In other cases, it meant finding pedagogical value in previously inconspicuous places, as Adelaide points out: 'We now look at things and realize they have educational value. Before, I didn't think that an exhibition of the painter Almada Negreiros was meaningful to discuss with students in teacher practicum'.

Another aspect of teaching practice that gained relevance, according to the teachers' voices, was collaborative work. Although this was a group that had previously worked together in past projects, this particular workshop allowed teacher educators to strengthen their conviction in collaborative, integrated and cross-curricular work, for the benefit of students' learning and the quality of their teaching. Adelaide and Carla present the most meaningful statements:

Adelaide: I think that a working group is important... to see ideas. Because this [GE] is a broad education perspective. You can do many things, right? And move in different directions. So, maybe, it is useful to see other strategies.

Carla: What we are doing here takes time, of course... it requires effort. But we like it because each one of us finds ... each one of us can make its contribution and receive something in return that we can use to improve our work. This dimension is very important.

Collaboration and the partnerships created both between the teachers and between the teachers and the researcher was a crucial aspect in providing the necessary support for reflection and change. Rita recalls how important it was for her to be in a group where teachers 'exchanged ideas about resources and activities, shared stories about their students' reactions and progress', as it helped her overcome her initial anxieties and 'conceptual confusion'. Kate shares the same point of view adding: 'I've been alone for a very long time [...] and from the moment I started to integrate this group and working with all of you, I felt different. I feel more supported now.'

Teachers also addressed the need to work together with other teacher educators in their department, particularly those in the STEM area, in order to infuse a global perspective and ethos in teacher education curricula:

Fatima: We did this with our 'mini-group', but surely if we had math or science teachers here we could... articulate the different areas and give them a sense according to a global perspective. And students could also take advantage of it, it would be beneficial for them if we were able to contribute to an education that is more ... 
Miriam: ....integrated, is not it?

Fatima: Yes, more integrated... To a real global education.

\section{Professional identity}

Regarding professional identity, participation in this collaborative workshop allowed teacher educators to reflect about and make sense of their own academic and professional paths, bridging past, present and future together. According to Laura, a teacher in an early stage of her career, taking part in this workshop gave her 'access to theoretical frameworks and studies that helped [her] to reflect about [her] own path as a student and as a teacher'. Working according to a GE perspective also encouraged teachers to reflect about the wider purposes of education in a globalized, multicultural and constantly changing world. Rita mentions how GE helped her 'think about the true meaning of education, namely what teacher education and prospective teachers should be like'. Carla, for her part, discovered that this educational perspective is aligned with her own beliefs about the purposes of education, which made her feel 'more comfortable and supported in [her] choices'.

Hence, throughout this workshop, teacher educators worked on personal vision building and saw how their pedagogical and didactic choices were connected to the purposes of GE. This allowed them to give practical and moral meaning to their profession, as Adelaide explains:

GE makes me think and search for other things that justify what I do or what I want to do ... because it allows me... it makes me think about the choices - what I have to think about when I choose a specific content, what is the most important thing to teach at that moment, what is more important for my students to learn [...] It makes me rethink the objectives of what is mandatory to do today, or what should be mandatory.

The workshop, then, stimulated a 'psychological shift' (Rodgers \& Scott 2008) in how teachers thought about themselves as teachers, leading them to assume new commitments to their students, to their peers, and to themselves as global citizens. Kate and Carla emphasized the role of loC in welcoming students from other countries 'in a more appropriate and inclusive manner'. Laura, in turn, highlights her responsibility to her peers, and the need to 'continue the dynamics initiated here, to improve them, and to serve as a spokesperson for these experiences'. In more concrete terms, Fatima suggests that the teacher educators who participated in this workshop should act as drivers of change, organizing their own collaborative workshops in the future to include other teachers and support dissemination of loC across the university:

Imagine that, at the beginning of the year, I would do some training sessions for other teachers on how to manage and internationalize the curriculum in this area. People would then be free to work with it or not ... and to meet once a month to present the work or the difficulties they had. But it could open up horizons...

Finally, Kate introduces another important aspect related to teachers' professional identity. In her own words, participation in this workshop 'fostered confrontation between what we think and how we act, that is, in the coherence between principles that we stand for and what we do'. This statement suggests that the ethos that characterizes a teacher as being internationalized cannot be switched on during teaching and switched off once teaching is finished. As Sanderson (2008) underlines, it is a 'whole-of-person transformation'. Therefore, if teacher educators want to educate globally competent and responsible teachers, they need to develop these competences themselves and act accordingly. This will allow them to better respond to the impact of neoliberal and market driven forces on their profession and on education in general, contributing to an internationalization that has more global and intercultural interests at heart.

\section{Concluding remarks}

This study aimed to understand the impact of an loC workshop on the perceived professional development of seven teacher educators. To achieve this goal, academics' discourses in a focus group were analyzed according to the principles of thematic analysis. Results of the analysis suggest that the workshop presented a meaningful opportunity for teacher educators, regardless of their working experience and roles, to reconstruct their professional knowledge and teaching practice around new and relevant topics, to (re)discover the importance of working collaboratively, and to change several aspects of their teaching identities, leading them to assume new commitments to themselves, to their students and to their peers.

These results, however, should be taken with a grain of salt. Not only is there a substantial amount of analysis still to be done, but also many of the above findings need to be triangulated with the transcripts of the sessions, and the results of the projects that are still under development. It should also be noted that findings are based 
on teachers' self-reporting. Classroom observation, for instance, could have corroborated or disproved these results. This is something the teachers themselves are aware of, as evidenced by Adelaide, who says, 'what we do and what we say to the students deserves to be analyzed. And maybe this is where we changed the most, from a professional point of view'. One should also bear in mind that this was an exploratory study that affected a small number of teacher educators and course units in one Education Department in Portugal. This means that results cannot be generalized. Furthermore, teacher educators were all working in the same disciplinary area, had similar professional backgrounds, and had an extensive international experience, which seems to be beneficial for loC. Hence, more studies with a more diverse group of teachers are needed to corroborate and inform these findings.

Another limitation of the study is related with the nature of professional development itself, which is a process over time and not a just-in-time training event. Teachers often alluded to the fact that GE is a complex perspective that requires more time (more cycles of action research) for them to incorporate it in their professional habitus. A more accurate and comprehensive evaluation would be a matter of whether there is evidence that the process of loC becomes routine over some years and not just a one-off experiment as a consequence of the workshop. Therefore, a follow-up project would be useful to contribute to a more sustainable and sustained process that is embraced by the whole academic community.

Despite these limitations, we believe that these findings can shed some light on the professional development of teacher educators, an area that has been long neglected in educational research. In this respect, we offer some tentative recommendations that may hopefully inspire other researchers and educational developers working with loC (Table 3).

[Table 3. Recommendations for a professional development program in loC]

\section{References}

Beelen, J., \& Jones, E. (2015). Redefining Internationalization at Home. In A. Curaj, L. Matei, R. Pricopie, J. Salmi, \& P. Scott (Eds.), The European Higher Education Area: Between Critical Reflections and Future Policies (pp. 67-80). Dordrecht: Springer.

Braun, V., \& Clarke, V. (2006). Using thematic analysis in psychology. Qualitative Research in Psychology, 3(2), 77-101.

Clifford, V. (2009). Engaging the disciplines in internationalising the curriculum. International Journal for Academic Development, 14(2), 133-143.

Childress, L. (2010). The Twenty-First Century University: Developing Faculty Engagement in Internationalization. New York: Peter Lang.

Council of Europe (2002). The Maastricht Global Education Declaration: European Strategy Framework for Improving and Increasing Global Education in Europe to the Year 2015, available at: https://www.coe.int/t/dg4/nscentre/GE/GE/Maastricht_Global_Education_Declaration_EN.pdf (accessed 19 May 2017).

De Wit, H., \& Beelen, J. (2013). Socrates in the low countries: Designing, implementing and facilitating internationalisation of the curriculum at the Amsterdam University of Applied Sciences. In J. Ryan (Ed.), CrossCultural Teaching and Learning for Home and International Students: Internationalisation of Pedagogy and Curriculum in Higher Education (pp. 156-167). Abingdon: Routledge.

Darling-Hammond, L., \& Lieberman, A. (2013). Teacher Education Around the World: Changing Policies and Practices. Abingdon: Routledge.

Goodnough, K. (2011). Examining the long-term impact of collaborative action research on teacher identity and practice: the perceptions of K-12 teachers. Educational Action Reseach, 19(1), 73-86.

Goodwin, A. L. (2012). Globalization and the preparation of quality teachers: rethinking knowledge domains for teaching. In R. L. Quezada (Ed.), Internationalization of Teacher Education: Creating Globally Competent Teachers and Teacher Educators for the 21st Century (pp. 19-32). Abingdon: Routledge. 
Green, W., \& Whitsed, C. (Eds.) (2015). Critical Perspectives on Internationalising the Curriculum. Rotterdam: Sense Publishers.

Huberman, M. (1989). The professional life cycle of teachers. Teachers College Record, 91, 31-57.

Kemmis, S., \& McTaggart, R. (2007). Participatory action research: Communicative action and the public sphere. In N.K. Denzin \& Y.S. Lincoln (Eds.), Handbook of Qualitative Research (2nd edition) (pp. 271-330). Thousand Oaks: Sage.

Krueger, R.A., \& Casey, M.A. (2015). Focus Groups: A Practical Guide for Applied Research (5th edition). Thousand Oaks: Sage.

Leask, B. (2007). International teachers and international learning. In E. Jones \& S. Brown (Eds.), Internationalising Higher Education (pp. 86-94). Abingdon: Routledge.

Leask, B. (2015). Internationalizing the Curriculum. London: Routledge.

Leask, B., Beelen, J., \& Kaunda, L. (2013). Internationalisation of the curriculum: International approaches and perspectives. In H. de Wit, F. Hunter, L. Johnson, \& H.-G. van Liempd (Eds.), Possible Futures: The Next 25 years of Internationalisation of Higher Education (pp. 187-203). Amsterdam: European Association for International Education.

Leask, B., \& Bridge, C. (2013). Comparing internationalisation of the curriculum in action across disciplines: theoretical and critical perspectives. Compare: A Journal of Comparative and International Education, 43(1), 79-101.

Lewin, K. (1946). Action research and minority problems. Journal of Social Issues, 2(4), 34-46.

Lourenço, M., Andrade, A.I., \& Sá, S. (2014). Diversidade linguística e formação contínua de educadoras de infância: que possibilidades de desenvolvimento profissional? [Linguistic diversity and early years teacher education: Which possibilities for continuing professional development?]. In A. I. Andrade, M. H. Araújo e Sá, R. M. Faneca, F. Martins, A. S. Pinho, \& A. R. Simões (Eds.), A diversidade linguística nos discursos e práticas de educação e formação (pp. 359-379). Aveiro: UA Editora.

Luxon, T., \& Peelo, M. (2009). Internationalisation: its implications for curriculum design and course development in UK higher education. Innovations in Education and Teaching International, 46(1), 51-60.

O'Connor, K., \& Zeichner, K. M. (2011). Preparing US teachers for critical global education. Globalisation, Societies and Education, 9(3-4), 521-536.

Patrick, K. F., Macqueen, S., \& Reynolds, R. (2014). Pre-service teacher perspectives on the importance of global education: world and classroom views. Teachers and Teaching: Theory and Practice, 20(4), 470-482.

Porter, A. C., Garet, M. S., Desimone, L., Yoon, K. S., \& Birman, B. F. (2000). Does Professional Development Change Teaching Practice: Results from a Three-Year Study. Washington, DC: Department of Education.

Quezada, R. L. (2012). Internationalization of Teacher Education: Creating Globally Competent Teachers and Teacher Educators for the 21st Century. London: Routledge.

Rodgers, C. R., \& Scott, K. H. (2008). The development of the personal self and professional identity in learning to teach. In M. Cochran-Smith, S. Feiman-Nemser, D. Mclntyre, \& K. Demers (Eds.), Handbook of Research on Teacher Education, 3rd ed (pp. 732-755). New York: Routledge.

Sanderson, G. (2008). A foundation for the internationalization of the academic Self. Journal of Studies in International Education, 12(3), 276-307.

Sawir, E. (2011). Academic staff response to international students and internationalising the curriculum: the impact of disciplinary differences. International Journal for Academic Development, 16(1), 45-57.

Sawir, E. (2013). Internationalisation of higher education curriculum: the contribution of international students. Globalisation, Societies and Education, 11(3), 359-378. 
Schleicher, A. (2012). Preparing Teachers and Developing School Leaders for the 21st Century: Lessons from Around the World. Paris: OECD Publishing.

Shulman, L. (2004). Knowledge and teaching foundations of the new reform. In P. Hutchings (Ed.), Teaching as Community Property - Essays on Higher Education (pp. 84-113). San Francisco: Jossey-Bass.

Stohl, M. (2007). We have met the enemy and he is us: The role of the faculty in the internationalization of Higher Education in the coming decade. Journal of Studies in International Education, 114(3), 359-372.

Tye, K. A. (2014). Global Education: a worldwide movement. An update. Policy Futures in Education, 12(7), 855-871.

Yin, R. K. (2009). Case Study Research: Design and Methods (4th edition). Thousand Oaks: Sage.

Zeichner, K. M. (2010). Preparing globally competent teachers: A U.S. perspective. Kansas City: NAFSA.

Zhao, Y. (2010). Preparing globally competent teachers: A new imperative for teacher education. Journal of Teacher Education, 61(5), 422-431.

Zinser, R. (2012). A curriculum model of a foundation for educating the global citizens of the future. On the Horizon, 20(1), 64-73. 
Table 1. Description of the participants

\begin{tabular}{|c|c|c|c|c|c|}
\hline $\begin{array}{c}\begin{array}{c}\text { Fictional } \\
\text { names }\end{array} \\
\text { nat }\end{array}$ & $\begin{array}{c}\text { Working } \\
\text { years }\end{array}$ & Background area & Disciplinary area & Other roles at the University & International experience \\
\hline Adelaide & 35 & Language Didactics & Language Didactics & $\begin{array}{l}\text { Course Director, Research Group } \\
\text { Coordinator, Lab Coordinator, } \\
\text { Member of the Scientific Committee }\end{array}$ & $\begin{array}{l}\text { Conducted part of her PhD abroad; has coordinated } \\
\text { and is a consultant for international research projects; } \\
\text { regularly supervises international students. }\end{array}$ \\
\hline Carla & 31 & Language Didactics & Language Didactics & Lab Coordinator & $\begin{array}{l}\text { Married a French citizen and went regularly to France } \\
\text { for } 12 \text { years; conducted part of her PhD abroad; has } \\
\text { been and still is a member of international research } \\
\text { teams; regularly supervises international students from } \\
\text { Brazil. }\end{array}$ \\
\hline Fatima & 38 & Language Didactics & Language Didactics & $\begin{array}{l}\text { Course Director, } \\
\text { Member of the Direction Board }\end{array}$ & $\begin{array}{l}\text { Reader for Portuguese Language at the University of } \\
\text { Burgundy (France); secretary of the committee of an } \\
\text { international association; has supervised international } \\
\text { students and participated in international projects. }\end{array}$ \\
\hline Kate & 25 & Teacher Education & Supervision & Practicum Coordinator & $\begin{array}{l}\text { Was born and raised in Mozambique; coordinated a } \\
\text { non-governmental organization for development in Sao } \\
\text { Tome and Principe, where she lived for one year; has } \\
\text { supervised international students; has an international } \\
\text { family scattered across the globe. }\end{array}$ \\
\hline Laura & $<1$ & $\begin{array}{l}\text { Accounting, Teacher } \\
\text { Education }\end{array}$ & Education & 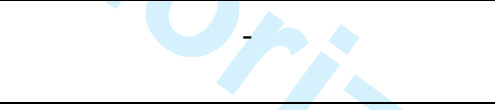 & $\begin{array}{l}\text { Was born and raised in Brazil, lived in Portugal for } 9 \\
\text { years; has participated in international projects and } \\
\text { scientific events. }\end{array}$ \\
\hline Miriam & 37 & Language Didactics & Language Didactics & $\begin{array}{l}\text { Course Director, } \\
\text { Lab Coordinator }\end{array}$ & $\begin{array}{l}\text { Conducted part of her postgraduate studies abroad; } \\
\text { regularly supervises international students; has } \\
\text { participated in international projects and scientific } \\
\text { events. }\end{array}$ \\
\hline Rita & 15 & Language Didactics & Language Didactics & Course Vice-Director & $\begin{array}{l}\text { Coordinated an international research project; has been } \\
\text { and still is a member of international research teams; } \\
\text { regularly participates in scientific meetings and events. }\end{array}$ \\
\hline
\end{tabular}


Table 2. Themes and sub-themes emerging from data analysis.

\begin{tabular}{ll}
\hline Themes & Sub-themes \\
\hline Professional knowledge & $\begin{array}{l}\text { Knowledge and understanding of global education } \\
\text { Knowledge and understanding of internationalization } \\
\text { (Broader) understanding of the curriculum }\end{array}$ \\
\hline Teaching practice & $\begin{array}{l}\text { Extension of the pedagogical and didactic repertoire } \\
\text { Valorization of collaborative work }\end{array}$ \\
\hline Professional identity & $\begin{array}{l}\text { Reflection about one's academic and professional path } \\
\text { Reflection about the aims of education } \\
\text { Justification of pedagogical and didactic choices } \\
\end{array}$ \\
& Assumption of new commitments \\
\hline
\end{tabular}

14

15

16

17

18

19

20

21

22

23

24

25

26

27

28

29

30

31

32

33

34

35

36

37

38

39

40

41

42

43

44

45

46

47

48

49

50

51

52

53

54

55

56

57

58

59 
Table 3. Recommendations for a professional development program in loC.

\section{The process of loC seems to be more effective when:}

- Academics are not cast in the role of passive participants in a process, but are recognized as the source of change and transformation.

- Academics work in disciplinary teams and cultivate communities of research practice.

- Transformative and emancipatory methodologies, such as participatory action research, are used.

- There is an environment of trust that not only promotes critical conversations about learning and teaching in higher education, but also questions dominant paradigms and knowledge frameworks.

- There is an external facilitator who acts as a 'critical friend', providing tangible support and genuine encouragement, as well as ideas for exploration and experimentation.

- Participants in the process act as drivers of change, supporting further growth and improvement inside the academic community. 
- Knowing and sharing

Stage 1

(two months)
Stage 2

(three months)

- Planning and collaborating

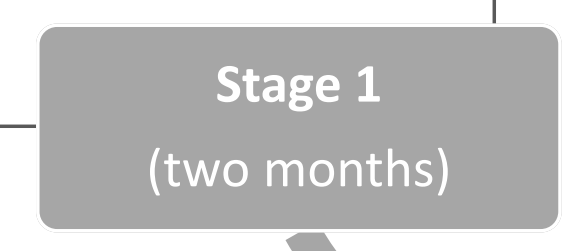

\section{- Acting and} developing

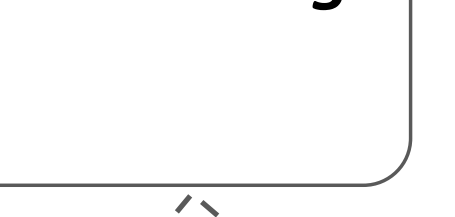

Stage 4

(three months)

- Evaluating and reflecting 